\title{
New data on the morphology and taxonomy of three species of Rhabdochona (Nematoda: Rhabdochonidae) parasitizing fishes in India
}

\author{
František Moravec ${ }^{1}$, Tomáš Scholz ${ }^{1}$, Anirban Ash ${ }^{1,2}$ and Pradip Kumar Kar ${ }^{3}$ \\ ${ }^{1}$ Institute of Parasitology, Academy of Sciences of the Czech Republic, Branišovská 31, 37005 České Budějovice, Czech \\ Republic; \\ ${ }^{2}$ Faculty of Sciences, University of South Bohemia, Branišovská 31, 37005 České Budějovice, Czech Republic; \\ ${ }^{3}$ Jhargram Raj College, Jhargram, Paschim Medinipur, West Bengal, India
}

\begin{abstract}
Specimens of three little-known species of Rhabdochona (Nematoda: Rhabdochonidae) were collected during occasional examinations of some freshwater fishes in India: R. (Rhabdochona) hellichi turkestanica (Skryabin, 1917) in Schizothorax sp. (Cyprinidae, Cypriniformes) from the Lodhomakhola and Rangit Rivers, West Bengal and Sikkim, respectively; $R$. (R.) hospeti Thapar, 1950 in Tor sp. (Cyprinidae) from the Rangit River; and R. (Globochona) mazeedi Prasad et Sahay, 1965 in Clupisoma garua (Hamilton) (Schilbeidae, Siluriformes) from the Farakka Dam Lake, West Bengal. Their detailed light and electron microscopical studies revealed some taxonomically important, previously not observed features and made possible their redescription. Fourth-stage larvae of $R$. hospeti are described for the first time. Rhabdochona hellichi turkestanica (syns. R. denudata filamentosa Bykhovskaya-Pavlovskaya, 1936, R. kashmirensis Thapar, 1950, R. schizothoracis Siddiqi et Khattak, 1984) is proposed as a subspecies, differing from the nominotypical subspecies $R$. hellichi hellichi (Šrámek, 1901) mainly in the shape of the distal end of the left spicule, molecular data and geographical distribution. Rhabdochona moraveci Katoch et Kalia, 1991 (a homonym to R. moraveci Duggal et Kaur, 1987) is renamed $R$. indica nom. $\mathrm{n}$. The following six species are considered new junior synonyms of $R$. hospeti: Comephronema [sic] mackiewiczi Malhotra et Rautela, 1984, Rhabdochona moraveci Duggal et Kaur, 1987, R. bifidum Kakar et Bilqees, 2007, R. uvaginus Kakar et Bilqees, 2007, R. bolani Kakar, Bilqees et Ahmad, 2008 and R. cephalodiverticula Kakar, Bilqees et Ahmad, 2008. Rhabdochona edentati Paul et Majumdar, 1994 is considered a species incertae sedis.
\end{abstract}

Keywords: parasitic nematode, Rhabdochona, morphology, taxonomy, freshwater fish, Schizothorax, Tor, Clupisoma, India

The nematode genus Rhabdochona Railliet, 1916 comprises very numerous species parasitizing the intestine of freshwater fishes in all zoogeographical regions (MejíaMadrid et al. 2007, Moravec et al. 2008, Moravec 2010); the poorly described Rhabdochona edentati Paul et Majumdar, 1994 reported from a frog in India (Paul and Majumdar 1994) evidently does not belong to this genus and should be considered a species incertae sedis. Many new species of Rhabdochona are continually described mainly from previously little-explored regions in the Americas, Africa and Asia, so that the number of nominal species continues to increase quickly. However, even though some recently described species have also been studied using scanning electron microscopy (SEM), descriptions of the majority of these nematodes are inadequate and do not meet the requirements of present-day taxonomy (Moravec 2007). This particularly concerns the numerous species of Rhabdochona often poorly or erroneously described from India and Pakistan, none of which has so far been examined by SEM.
In fact, South-Asian species of Rhabdochona represent a perplexing group and a serious taxonomic problem. Moreover, as a rule, the type specimens of these species have not been deposited in recognised collections and are not available for re-examination. In this situation, the only solution of this problem is redescriptions based on topotypic and other newly collected materials and, where possible, a formal synonymy to reduce the evident inflation of Rhabdochona species in this region.

Occasional helminthological examinations of some freshwater fishes in India, carried out in March 2009, yielded specimens of three different, hitherto little-known species of Rhabdochona. Results of their detailed light and electron microscopical study are presented herein.

\section{MATERIALS AND METHODS}

Fishes were caught by local fishermen in West Bengal and Sikkim. Nematodes recovered from the digestive tract were fixed in hot $4 \%$ formaldehyde solution (a few of them in 100\% ethanol for subsequent DNA examination). For light micro-

Address for correspondence: F. Moravec, Institute of Parasitology, Biological Centre of the Academy of Sciences of the Czech Republic, Branišovská 31, 37005 České Budějovice, Czech Republic. Phone: +420 38777 5432; Fax: +420 38 5310388; E-mail: moravec@paru.cas.cz 
scopical (LM) examination, they were cleared with glycerine. Drawings were made with the aid of a Zeiss microscope drawing attachment. Specimens used for scanning electron microscopy (SEM) were postfixed in $1 \%$ osmium tetroxide, dehydrated through a graded acetone series, critical point dried and sputtercoated with gold; they were examined using a JEOL JSM-7401F scanning electron microscope at an accelerating voltage of $4 \mathrm{kV}$ GB low. All measurements are in micrometres unless otherwise stated. Fish names follow FishBase (Froese and Pauly 2010). Voucher specimens have been deposited in the Helminthological Collection of the Institute of Parasitology, Biology Centre of the Academy of Sciences of the Czech Republic, in České Budějovice (IPBCAS).

\section{RESULTS}

Family Rhabdochonidae Travassos, Artigas et Pereira, 1928

\section{Rhabdochona (Rhabdochona) hellichi turkestanica (Skryabin, 1917)}

Figs. 1, 2

Syns: Ichthyospirura turkestanica Skryabin, 1917; Rhabdochona denudata filamentosa Bykhovskaya-Pavlovskaya, 1936; R. kashmirensis Thapar, 1950; R. schizothoracis Siddiqi et Khattak, 1984.

Description: Medium-sized nematodes with transversely striated cuticle (Fig. 2D). Oral aperture hexagonal, with four dinstinct submedian sublabia, surrounded by four small submedian cephalic papillae and pair of lateral amphids (Figs. 1 D, 2 A-C). Prostom funnel-shaped; small basal prostomal teeth visible in lateral view (Fig. 1 $\mathrm{B}, \mathrm{C})$. Anterior margin of prostom armed internally with 14 small, forwardly directed teeth (3 dorsal, 3 ventral and 4 on each side) (Figs. 1 D, 2 A, C). Vestibule rather long (Fig. 1 A-C). Deirids small, bifurcate, situated near middle of vestibule or somewhat anterior to it (Figs. $1 \mathrm{~A}-\mathrm{C}$, 2 D). Tail of both sexes conical, with sharply pointed tip (Fig. 1 E, H, I, K).

Male (2 specimens): Length of body $10.72-10.74 \mathrm{~mm}$, maximum width 150-163. Prostom 24-27 long and 18 wide in lateral view. Length of vestibule including prostom 147-150. Muscular oesophagus 345-348 long, maximum width 30-33; glandular oesophagus 3.19-3.94 mm long, maximum width 105-114; length ratio of both parts 1:9-11. Length of vestibule with prostom and entire oesophagus forms $34-40 \%$ of body length. Nerve ring, excretory pore and deirids 189-219, 246-285 and 69-111, respectively, from anterior extremity (Fig. 1A). Preanal papillae: 9 pairs of subventral papillae and 1 pair of lateral papillae situated between second and third subventral pairs (counting from cloacal opening). Of 6 postanal pairs of papillae, second pair lateral, remaining subventral (Fig. $1 \mathrm{~K}$ ). Longitudinal ventral cuticular ridges (area rugosa) well developed. Left spicule long, 570-576 long; its shaft 318-339 long, representing 56-59\% of entire spicule length; distal tip of spicule widely bifurcate (Fig. 1 L). Right spicule 135-138 long, with distinct dorsal barb at distal tip, which may appear to be absent in certain position of spicule (Fig. $1 \mathrm{~F}, \mathrm{G}$ ). Length ratio of spicules 1:4.17-4.22. Tail 396-441 long.

Female (2 complete and 1 incomplete gravid specimens): Length of body of complete specimens 12.25 $16.09 \mathrm{~mm}$ (19.25 in incomplete specimen without anterior end containing vestibule and muscular oesophagus), maximum width 218-286. Prostom 27-38 long and 18-24 wide in lateral view. Length of vestibule including prostom 114-165. Muscular oesophagus 291-405 long, maximum width 24-36; glandular oesophagus 2.53-3.88 $\mathrm{mm}$, maximum width 126-144; length ratio of both parts $1: 8-9$. Nerve ring, excretory pore and deirids at 195-225, 324-327 and 78-81, respectively, from anterior extremity. Vulva postequatorial, $6.58-8.21 \mathrm{~mm}$ from anterior extremity (at $51-54 \%$ of body length). Vagina directed posteriorly from vulva. Fully developed eggs (containing larva) oval, thick-walled, size 39-45 × 21-27; thickness of wall 3; each bears distinct protuberance on either pole provided with broad filament of fibrous structure ca. 200 250 long (Figs. 1 M, 2 E, F). Tail 264-360 long (Fig. 1 E).

H o st: Schizothorax sp. (Cyprinidae, Cypriniformes).

Site of infection: Intestine.

L o c a lity: Lodhomakhola and Rangit Rivers (Tista River basin), West Bengal and Sikkim, India (collected 8 and 9 March 2009).

Prevalence and intensity: In 2 fish examined(1 from each locality); 10 and 2 specimens, respectively.

Deposition of voucher specimens: IPBCAS (Cat. No. N-48).

Comments. Because of their morphological similarity, Moravec (1975) synonymized the Central Asiatic species Ichthyospirura turkestanica Skryabin, 1917 and Rhabdochona filamentosa Bykhovskaya-Pavlovskaya, 1936, and R. kashmirensis Thapar, 1950 from Kashmir, with the European species Rhabdochona hellichi (Šrámek, 1901). Later R. hellichi was reported from Schizothorax spp. and Salmo trutta oxianus (Kessler) from the basins of the Rivers Indus and Amu-Darya in Afghanistan by Moravec and Amin (1978) and from Schizothorax plagiostomus Heckel in India (Himachal Pradesh) by Soota and Sarkar (1981). Sood (1988) also synonymized $R$. schizothoracis Siddiqi et Khattak, 1984, a species described from Schizothorax spp. in Pakistan, with $R$. hellichi.

Katoch and Kalia (1991) inadequately described Rhabdochona moraveci Katoch et Kalia, 1991 from Crossocheilus latius (Hamilton) and Schizothorax esocinus Heckel (both Cyprinidae) from Himachal Pradesh, India. However, this name is a homonym to $R$. moraveci Duggal et Kaur, 1987 (syn. of $R$. hospeti Thapar, 1950) and, therefore, a new name, Rhabdochona indica nom. n., is now proposed for this species. Since $S$. esocinus is reported by Fotedar and Dhar (1970) as a frequent host of Filochona (= Rhabdochona) kashmirensis, it may well be that the material of Katoch and Kalia from $S$. esocinus included this species. 

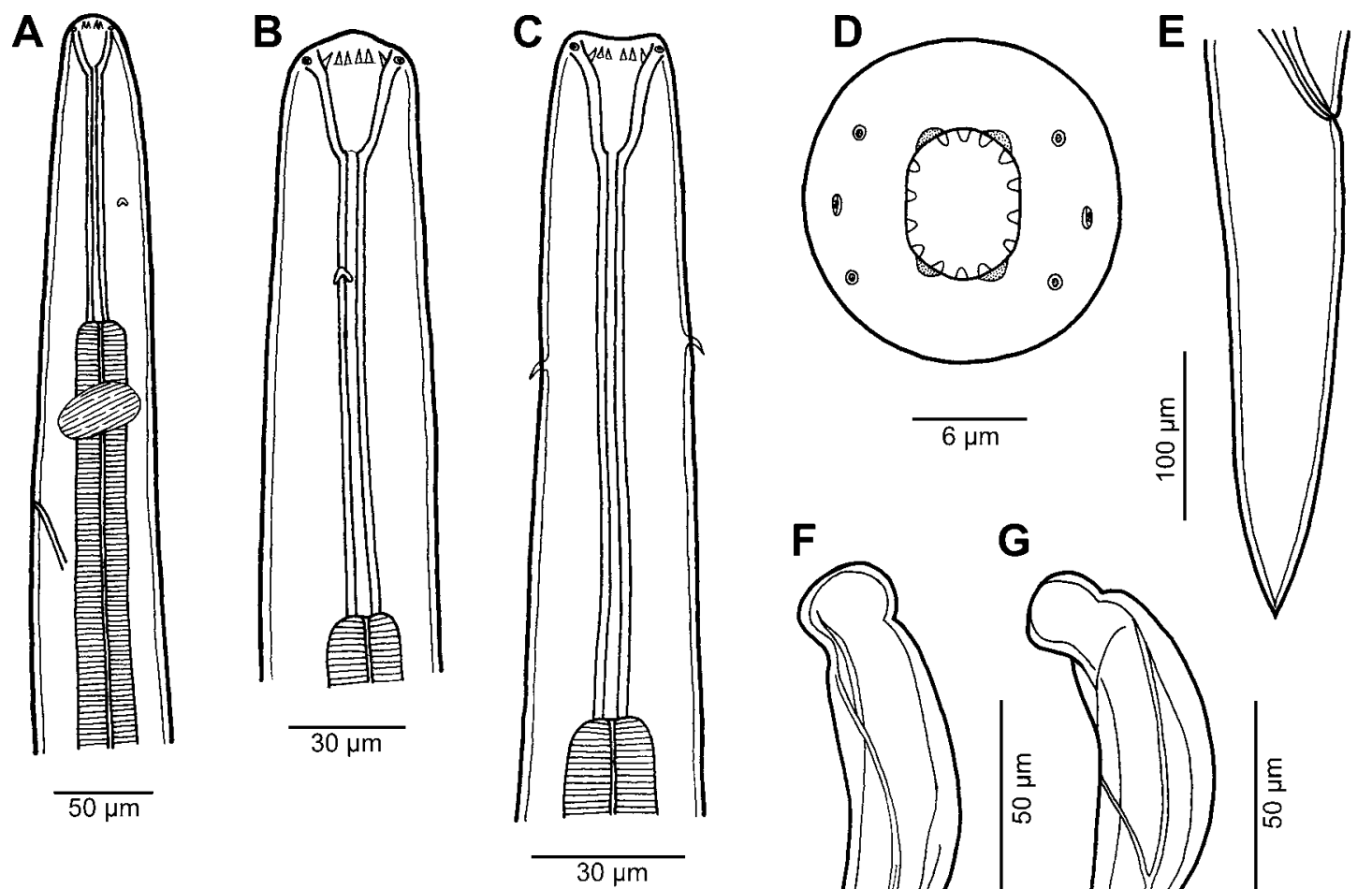

$\mathbf{F}$

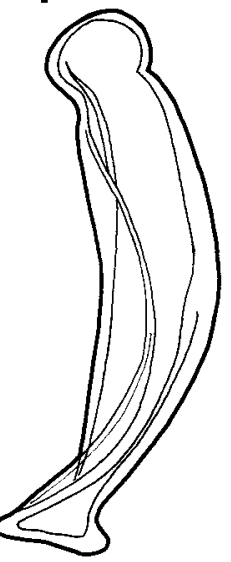

G

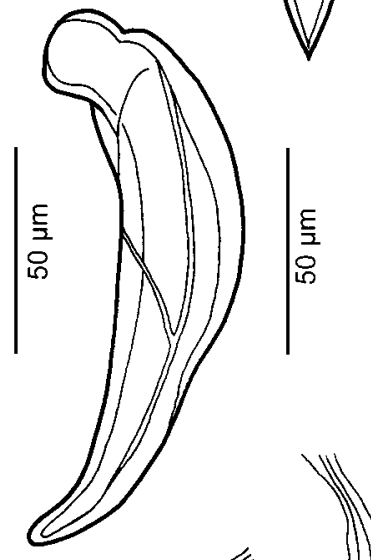

I

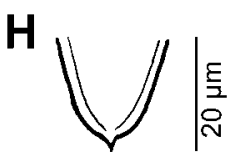

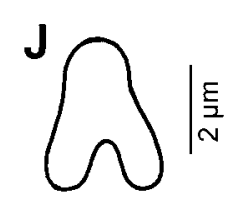

K

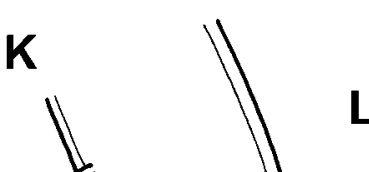

$\mathbf{L}$
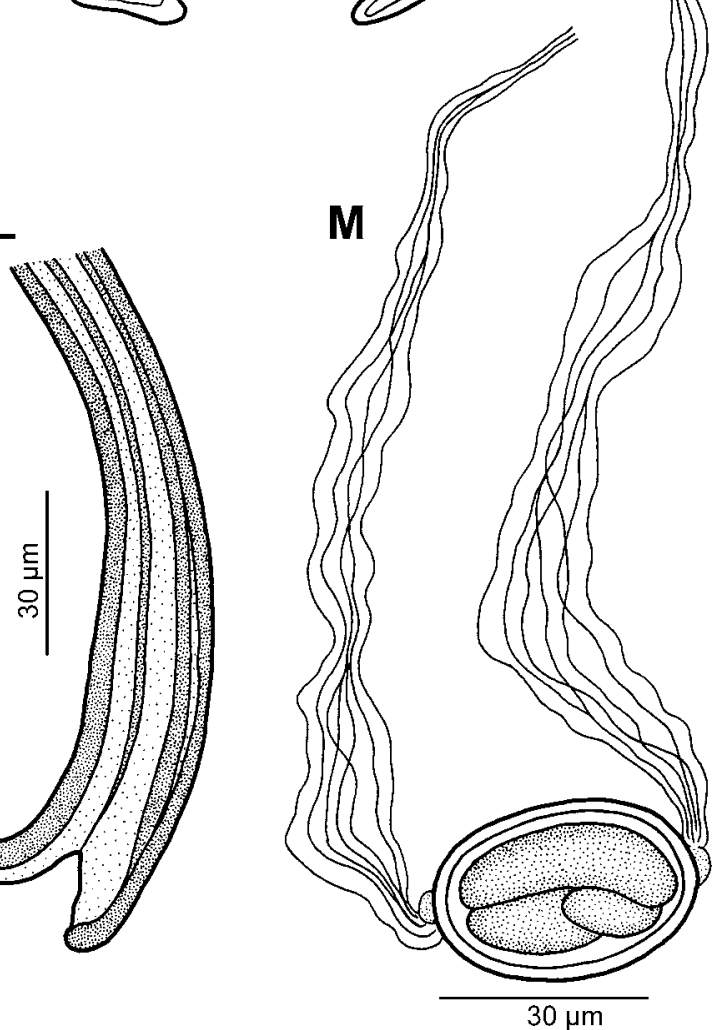

Fig. 1. Rhabdochona hellichi turkestanica (Skryabin, 1917) from Schizothorax sp. A - anterior end of male, lateral view; B, C - cephalic end of female and male, lateral and dorsoventral views; D - cephalic end, apical view; $\mathbf{E}$ - female tail, lateral view; F, G - same right spicule in different positions; $\mathbf{H}, \mathbf{I}$ - tail tip of male and female, respectively; $\mathbf{J}$-deirid; $\mathbf{K}$ - posterior end of male, lateral view; $\mathbf{L}$ - distal end of left spicule, lateral view; $\mathbf{M}$ - fully developed egg. 

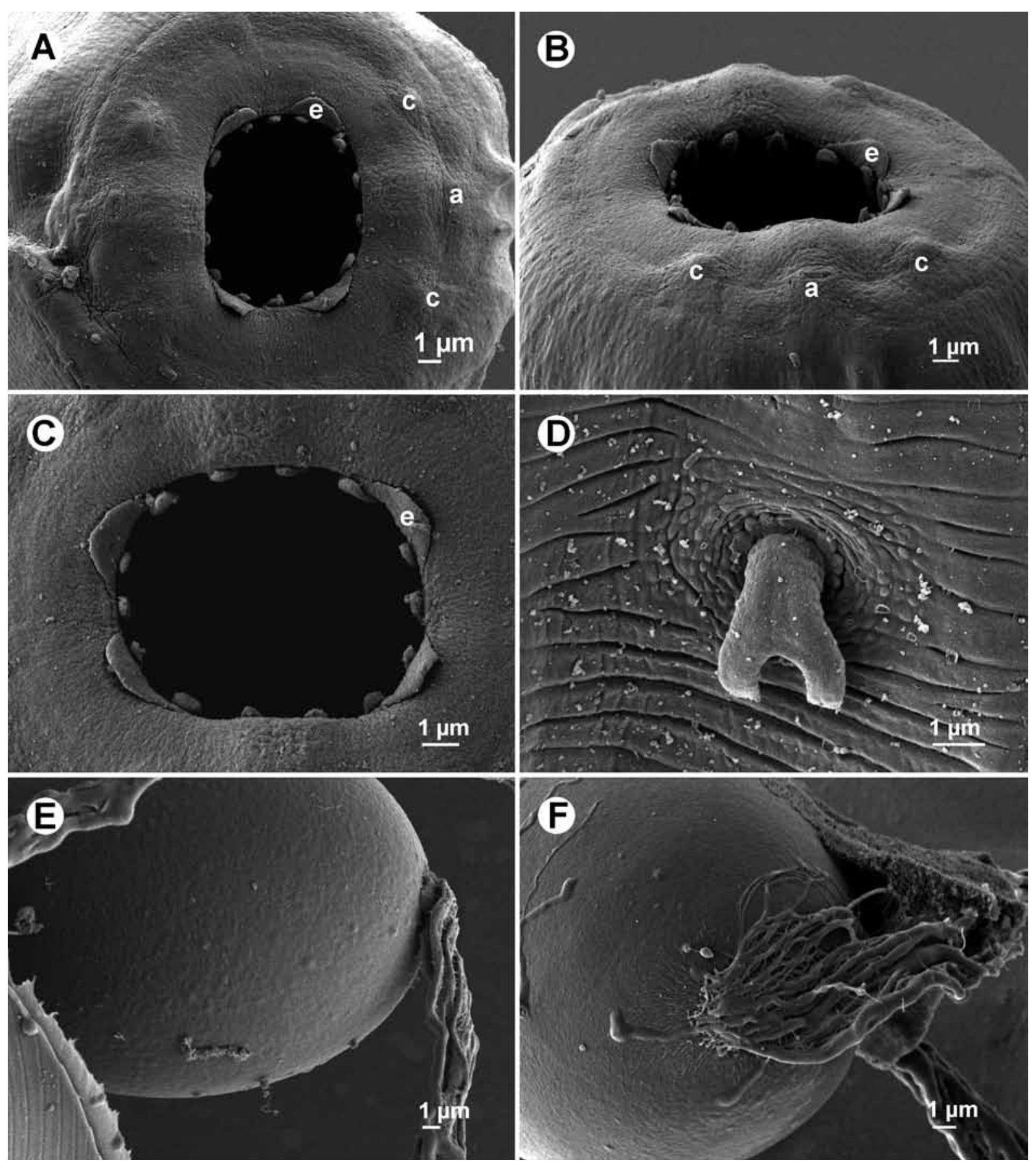

Fig. 2. Rhabdochona hellichi turkestanica (Skryabin, 1917) from Schizothorax sp., scanning electron micrographs. A, B - cephalic end, apical and lateral views; C - mouth, apical view; D - deirid; E - egg with polar filament, lateral view; F - attachment of egg polar filament, apical view. Abbreviations: a - amphid; c - cephalic papilla; e - sublabium.

The morphology of specimens of the present material is in a full agreement with the description of Rhabdochona hellichi provided by Moravec and Amin (1978) based on specimens from Afghanistan. Even though some small morphological differences between European and Asian specimens of $R$. hellichi were observed, especially in the shape of the distal end of the left spicule, these were considered to be within the intraspecific variability of this species (Moravec 1975, Moravec and Amin 1978).

However, recent molecular studies (Černotíková 2010) of $R$. hellichi specimens from Barbus barbus (Linnaeus) in the Czech Republic and those of the present material from India have revealed that these forms are genetically distant. Therefore, we suggest that the nematodes so far 
reported as $R$. hellichi or under synonyms from Central and South Asia represent a distinct subspecies, $R$. hellichi turkestanica (Skryabin, 1917). Its junior synonyms are R. filamentosa Bykhovskaya-Pavlovskaya, 1936, R. kashmirensis Thapar, 1950 and $R$. schizothoracis Siddiqi et Khattak, 1984. It differs morphologically from the nominotypical subspecies $R$. hellichi hellichi (Šrámek, 1901) mainly in having the ventral process of the distal tip of the left spicule distinctly longer than the dorsal process (Fig. 1 L) (vs. both processes approximately equally long). While the main hosts of $R$. h. hellichi are European species of Barbus, those of $R$. h. turkestanica are Asian representatives of Schizothorax and some related genera.

The examination by SEM, used for the first time in this species, revealed the presence of four well-developed sublabia and made it possible to observe in more detail the shape, size and distribution of prostomal teeth as well as the shape of deirids.

This subspecies was first recorded and inadequately described as Ichthyospirura turkestanica from females found by Skryabin (1917) in Schizothorax intermedius (McClelland) in Central Asia. According to hitherto data, $R$. hellichi turkestanica is distributed in basins of the Rivers Amu-Darya and Indus in Central Asia (Kirghizia, Turkmenia, Tadjikistan), Afghanistan, Pakistan and northern India (Kashmir), where it parasitizes mainly species of Schizothorax [S. intermedius (type host), S. labiatus (McClelland), S. plagiostomus, S. pseudaksaiensis Herzenstein], the related Schizopyge [S. curvifrons (Heckel), S. esocinus, S. niger (Heckel)] and Schizopygopsis (S. stoliczkai Steindachner), and, less often other cyprinids and other fishes (Skryabin 1917, 1923, Bykhovskaya-Pavlovskaya 1936, Thapar 1950, Dzhalilov 1964, Fotedar and Dhar 1970, Osmanov 1971, Ashurova 1973, Moravec 1975, Moravec and Amin 1978, Soota and Sarkar 1981).

\section{Rhabdochona (Rhabdochona) hospeti Thapar,}

\section{0}

Figs. 3-5

Syns: Rhabdochona barbi Karve et Naik, 1951; R. penangensis Furtado, 1965; R. ghaggari Sood, 1972; R. alii Kalyankar, 1972; R. labeonis Kalyankar, 1972; Comephronema [sic] mackiewiczi Malhotra et Rautela, 1984; Rhabdochona moraveci Duggal et Kaur, 1987; R. bifidum Kakar et Bilqees, 2007; R. uvaginus Kakar et Bilqees, 2007 (new synonymy); R. bolani Kakar, Bilqees et Ahmad, 2008 (new synonymy); $R$. cephalodiverticula Kakar, Bilqees et Ahmad, 2008 (new synonymy).

Description: Medium-sized nematodes with transversely striated cuticle (Fig. 4 D). Oral aperture hexagonal, with four distinct submedian sublabia, surrounded by four small submedian cephalic papillae and pair of lateral amphids (Figs. 3 C, 4 A-C). Prostom funnel-shaped; small basal prostomal teeth visible in lateral view (Fig. 3 B). Anterior margin of prostom armed internally with 14 small, forwardly directed teeth ( 3 dorsal, 3 ventral and 4 on each side, latter forming pairs) (Figs. $3 \mathrm{C}, 4 \mathrm{~A}-\mathrm{C}$ ). Prostom of fourth-stage larva armed with only 6 anterior teeth (Figs. 3 G, 5 A). Vestibule rather long (Fig. 3 A, B). Deirids of adults and fourth-stage larvae small, bifurcate, situated somewhat posterior to mid-length of vestibule (Figs. 3 A, B, D, F, J, 4 D, 5 B). Tail of both sexes conical, with sharply pointed tip (Figs. $3 \mathrm{E}, \mathrm{H}, \mathrm{I}, \mathrm{M}, 4 \mathrm{E}$ ).

Male (2 specimens): Length of body 10.12-11.14 mm, maximum width 141-153. Prostom 24 long and 18-21 wide in lateral view. Length of vestibule including prostom 162-168. Muscular oesophagus 357-366 long, maximum width 27-30; glandular oesophagus $3.94-4.01 \mathrm{~mm}$ long, maximum width 93-102; length ratio of both parts 1:11-16. Length of vestibule with prostom and entire oesophagus forms $41-44 \%$ of body length. Nerve ring, excretory pore and deirids situated 195-210, 252-261 and 111-117, respectively, from anterior extremity. Preanal papillae: 7 pairs of subventral papillae and 1-2 pairs of lateral papillae situated between second and third, and third and fourth subventral pairs (counting from cloacal opening). Of 6 postanal pairs of papillae, second pair lateral, remaining subventral (Figs. 3 M, 4 E). Longitudinal ventral cuticular ridges (area rugosa) moderately developed (Fig. 4 F). Left spicule 693-723 long; its shaft 345375 long, representing $50-52 \%$ of entire spicule length; distal tip somewhat narrowed, provided with cuticular membrane (Fig. 3 N). Right spicule 159-171 long, without distinct dorsal barb at distal tip (Fig. $3 \mathrm{M}$ ). Length ratio of spicules 1:4.2-4.4. Tail 342-396 long.

Female ( 2 gravid specimens; measurements of 2 female fourth-stage larvae in parentheses): Length of body 11.42-11.71 (6.62-7.39) mm, maximum width 150-156 (120). Prostom 227-230 (15-21) long and 21-24 (15) wide in lateral view. Length of vestibule including prostom 159-162 (120). Muscular oesophagus 378-423 (285-312) long, maximum width 36 (24-27); glandular oesophagus 3.85-3.94 (3.17-3.31) mm, maximum width 108 (99-102); length ratio of both parts 1:14-15 (1:1012). Nerve ring, excretory pore and deirids at 204-207 (156), 258-279 (210-216) and 96-117 (90-93), respectively, from anterior extremity (Fig. 3A). Vulva postequatorial, 6.96-7.26 (4.42-4.77) $\mathrm{mm}$ from anterior extremity, at 59-64 (65-67)\% of body length. Vagina short, directed posteriorly from vulva (Fig. $3 \mathrm{~K}$ ). Fully developed eggs (containing larva) oval, thick-walled, size 39-45 × 27-30 $(-)$; thickness of wall $2(-)$. Each egg bearing distinct protuberance on either pole provided with broad filament of fibrous structure ca. 150 long; filaments often frayed into more parts (Fig. 3 O, P). Tail 198-201 (108-147) long, with distinct small terminal cuticular spike (Fig. 3 E).

Hos t: Tor sp. (Cyprinidae, Cypriniformes).

Site of infection: Intestine.

L o cality: Rangit River at Jorethang, Sikkim, India (collected 9 March 2009). 

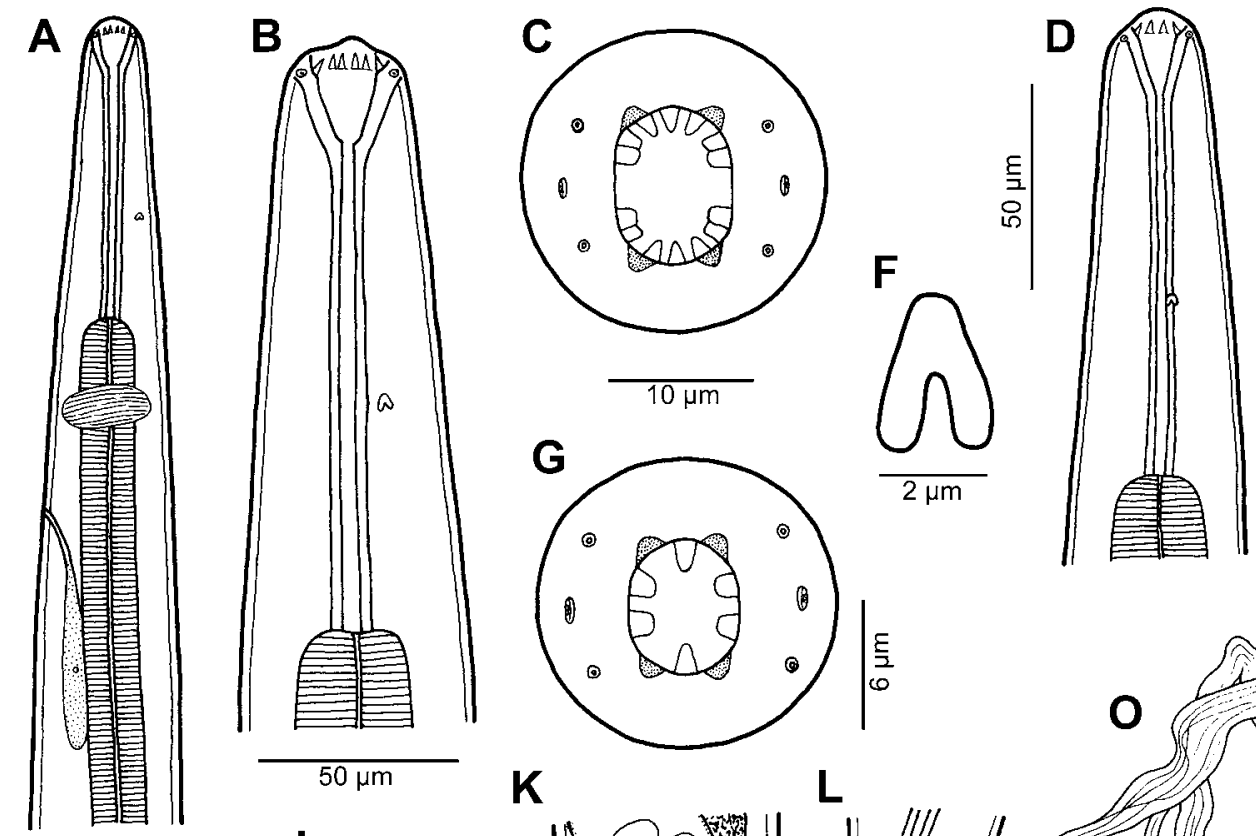

$\mathbf{E}$
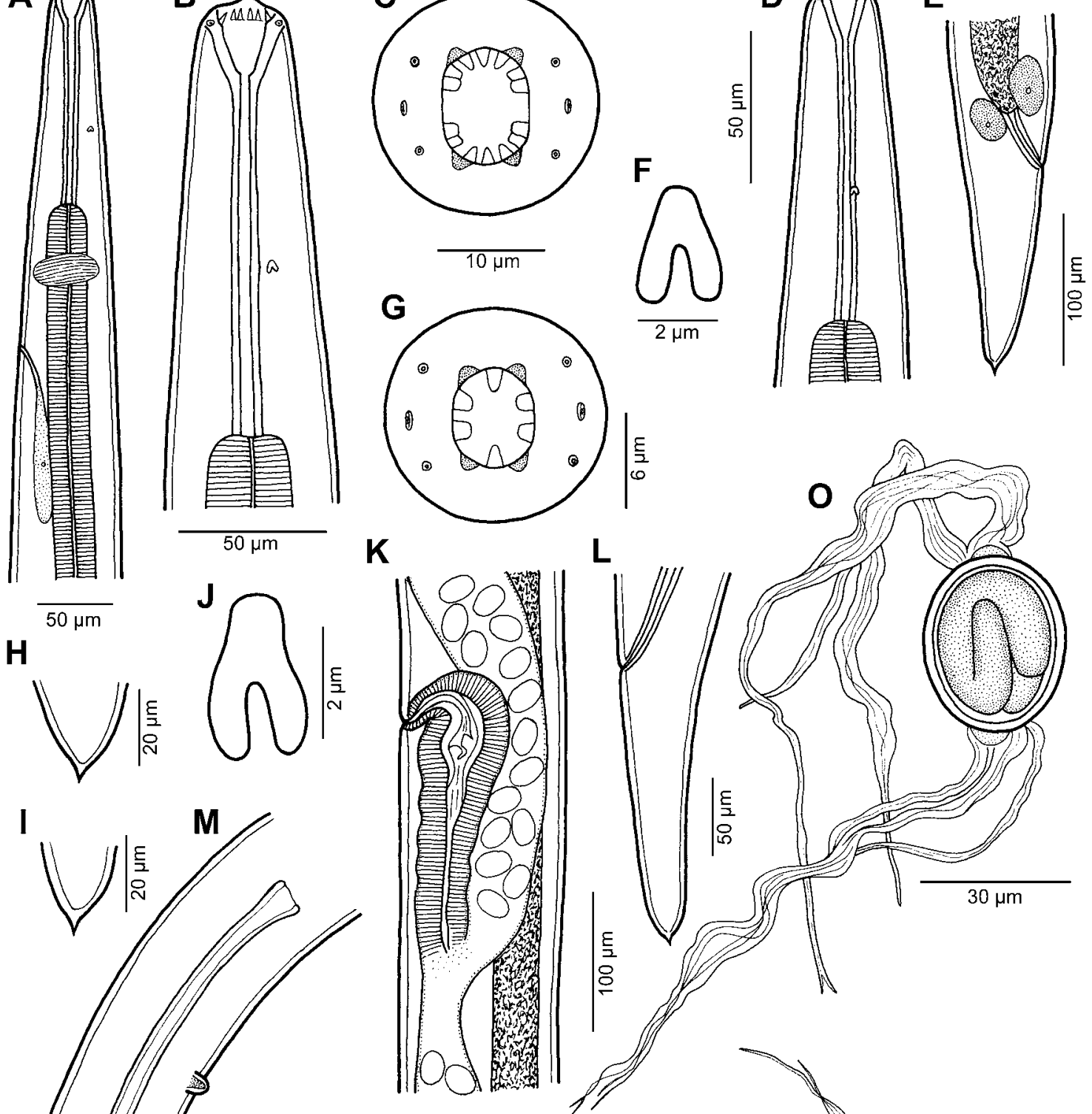

$\frac{\xi}{8}$

K
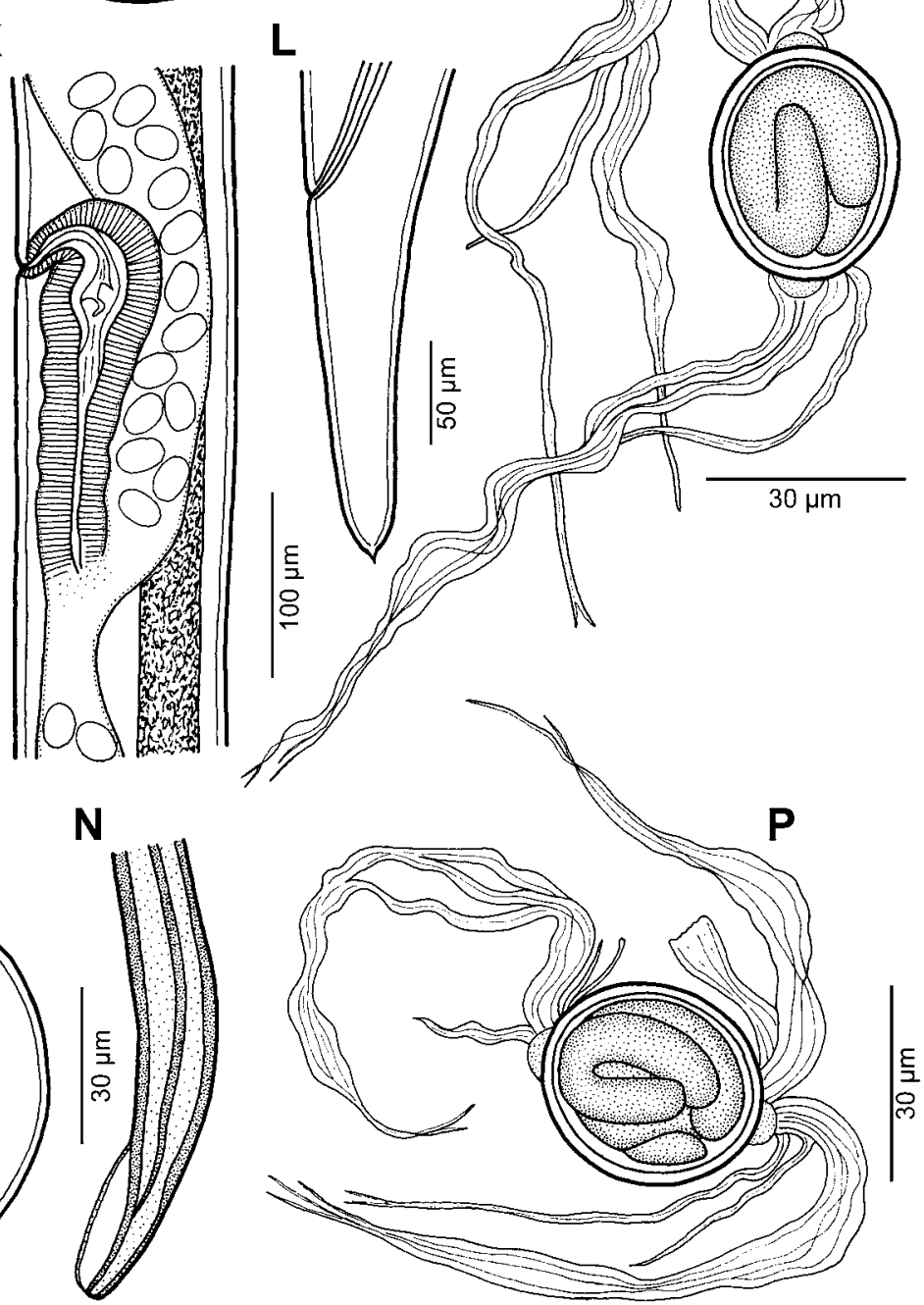

Fig. 3. Rhabdochona hospeti Thapar, 1950 from Tor sp. A - anterior end of female, lateral view; $\mathbf{B}$ - cephalic end of female, lateral view; $\mathbf{C}$ - cephalic end, apical view; D-G - fourth-stage larva (D, E - anterior end and tail, lateral views; $\mathbf{F}$ - deirid; $\mathbf{G}$ - cephalic end, apical view); H, I - tail tip of male and female, respectively; $\mathbf{J}$ - deirid; $\mathbf{K}$ - region of vulva, lateral view; $\mathbf{L}-$ tail of female, lateral view; $\mathbf{M}$ - posterior end of male, lateral view; $\mathbf{N}$ - distal end of left spicule, lateral view; $\mathbf{O}, \mathbf{P}$ - fully developed eggs. 

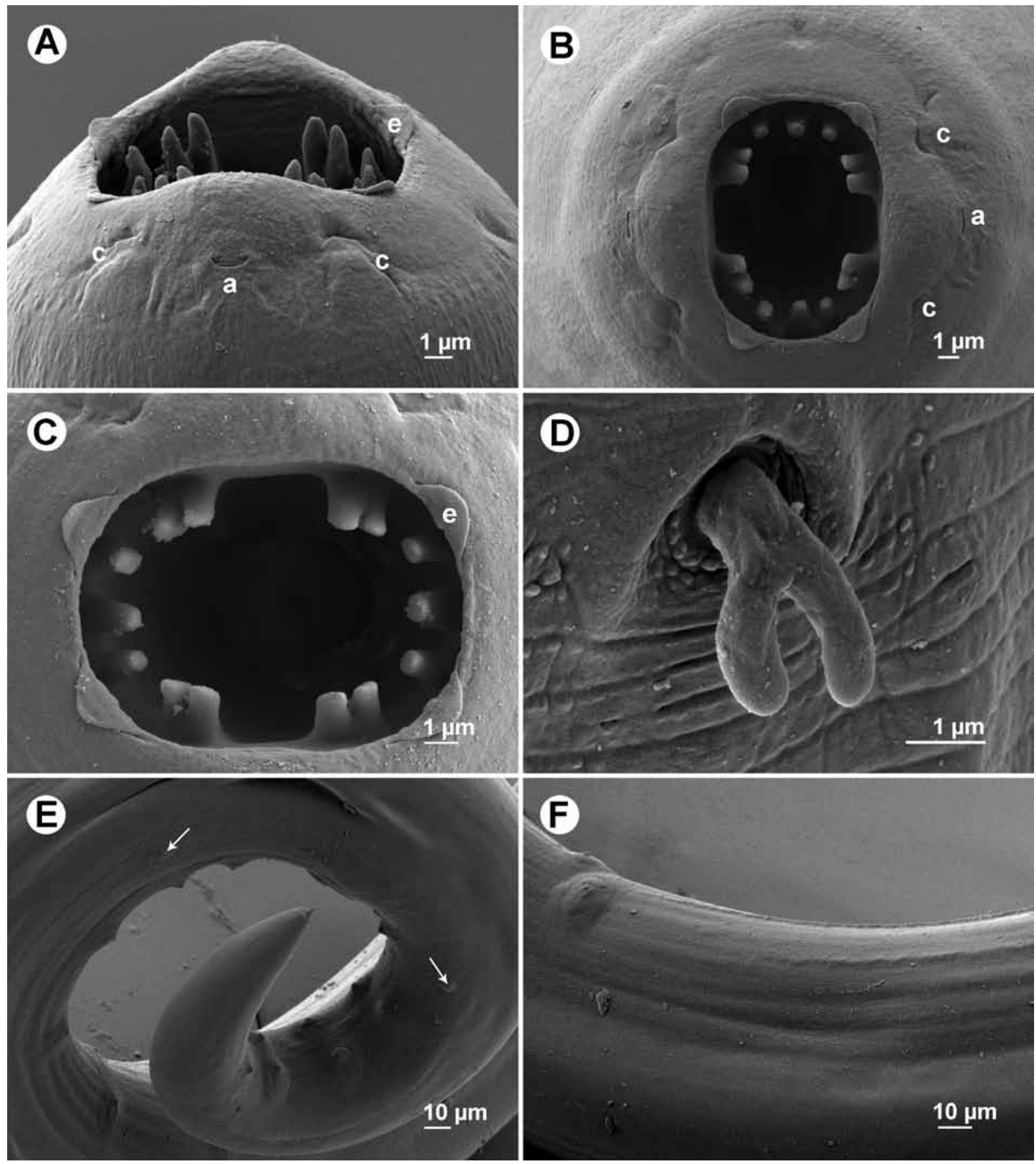

Fig. 4. Rhabdochona hospeti Thapar, 1950 from Tor sp., scanning electron micrographs. A, B - cephalic end, lateral and apical views; C - oral aperture, apical view; D - deirid; E - posterior end of male, sublateral view (arrows indicate lateral papillae); F - ventral cuticular ridges anterior to caudal papillae, sublateral view. Abbreviations: a - amphid; c - cephalic papilla; e - sublabium.

Prevalence and intensity: In 1 fish examined; 7 specimens.

Deposition of voucher specimens: IPBCAS (Cat. No. N-39).

Comments. The morphology of specimens of the present material is in agreement with that of $R$. hospeti, as redescribed by Moravec and Amin (1978). Originally this species was described by Thapar (1950) from a single female typified by filamented eggs, found in the host Tor tor (Hamilton) at Madras, India. Moravec (1975), while revising Eurasian species of Rhabdochona, designated the following five inadequately described species to be junior synonyms of $R$. hospeti: $R$. barbi Karve et Naik, 1951 from Hypselobarbus kolus (Sykes) and Tor khud- 

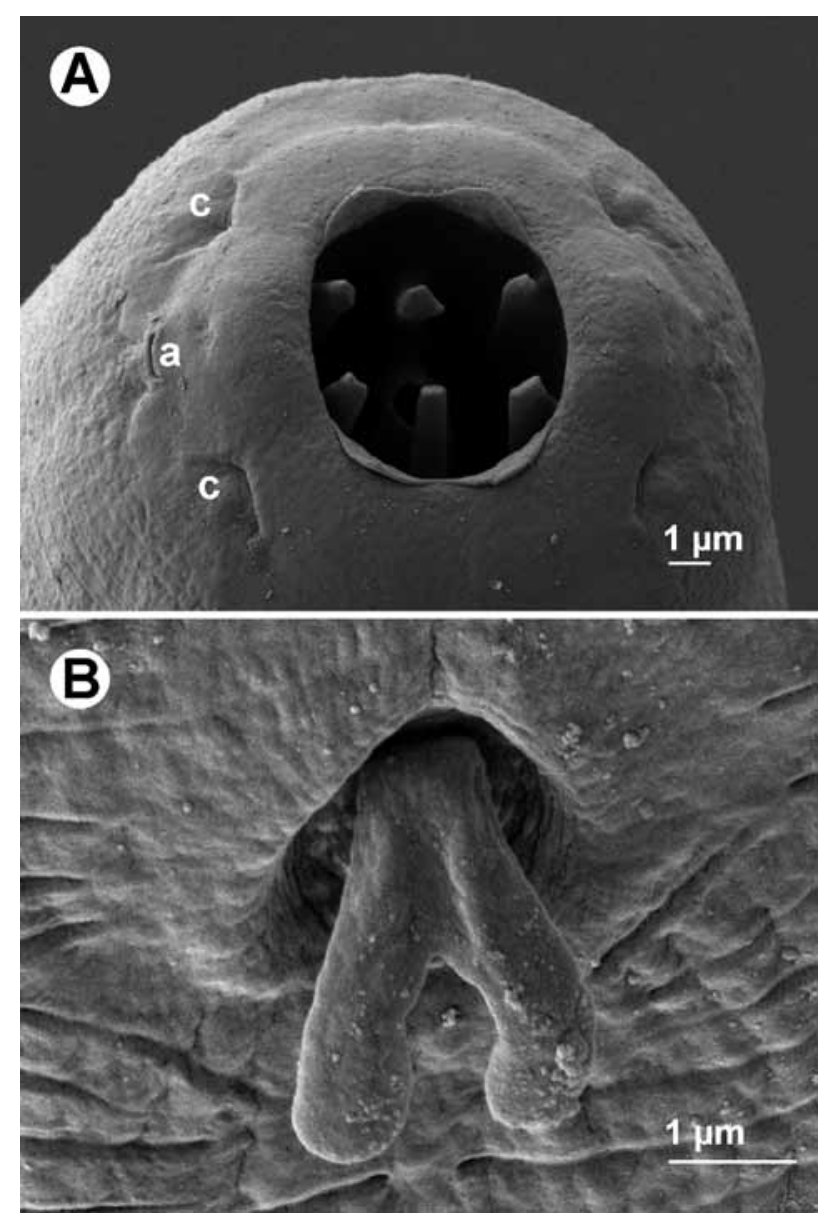

Fig. 5. Rhabdochona hospeti Thapar, 1950, scanning electron micrographs of fourth-stage larva from Tor sp. A-cephalic end; B - deirid. Abbreviations: a - amphid, c - cephalic papilla.

ree (Sykes) from Poona, India, $R$. penangensis Furtado, 1965 from Puntius binotatus (Valenciennes) from Malaysia, R. ghaggari Sood, 1972 from Tor tor from Chandigarh (Indus River basin), India, and R. alii Kalyankar, 1972 and R. labeonis Kalyankar, 1972, both from Labeo rohita (Hamilton) from Maharashtra, India (Karve and Naik 1951, Furtado 1965, Kalyankar 1972, Sood 1972); he also assigned to this species the nematodes misidentified by Verma (1972) as Rhabdochona bosei Sahay, 1966 (=R. garuai Agrawal, 1965 - see Moravec 1975) from the catfish Wallago attu (Bloch et Schneider) in India (Lucknow), considering this fish only a facultative host.

This was followed by Soota and Sarkar (1981) and Soota (1983); the former authors newly reported $R$. hospeti from Tor tor at the Solan fish market, Himachal Pradesh, India. However, later Sood (1989) again considered Rhabdochona alii, $R$. barbi, $R$. ghaggari and $R$. labeonis to be valid species, mentioning that $R$. ghaggari was reported by Siddiqi and Khattak (1983) from Tor tor in Pakistan. In our opinion, this re-validation of the above-mentioned species is not well founded and, considering the argumentation given by Moravec (1975), is not acceptable. On the contrary, an additional six species, all poorly described from Tor tor (type host of $R$. hospeti) or T. putitora (Hamilton) in India and Pakistan, can be considered junior synonyms of $R$. hospeti: Comephronema [sic] mackiewiczi Malhotra et Rautela, 1984, Rhabdochona moraveci Duggal et Kaur, 1987, R. bifidum Kakar et Bilqees, 2007, R. uvaginus Kakar et Bilqees, 2007, R. bolani Kakar, Bilqees et Ahmad, 2008 and $R$. cephalodiverticula Kakar, Bilqees et Ahmad, 2008 (see Malhotra and Rautela 1984, Duggal and Kaur 1987, Kakar and Bilqees, 2007a,b, Kakar et al. 2008). Moravec (2010) considered R. bifidum, $R$. bolani, $R$. cephalodiverticula and $R$. uvaginus to be species inquirendae. Some morphometrical data relating to some of these nematodes are evidently erroneous.

In many characters, $R$. hospeti resembles the Palaearctic species $R$. gnedini Skryabin, 1948. However, since the morphology of $R$. gnedini remains insufficiently known and both species occur in different zoogeographical regions, $R$. hospeti is retained as a separate species. Rhabdochona hospeti is also similar to $R$. hellichi (see above), from which it differs mainly in the shape of the distal tip of the left spicule, and partly by the arrangement and shapes of prostomal teeth (lateral teeth markedly flat, forming pairs) (Fig. 4 C). The SEM examination, used for the first time in this species, revealed the presence of four distinct submedian sublabia (Fig. 4 B, C) and ventral cuticular precloacal ridges in the male (Fig. 4 F), and enabled the determination the actual shape of deirids (Fig. 4 D).

The fourth-stage larva of $R$. hospeti is now described for the first time. In contrast to adults, these larvae have only six prostomal teeth (instead of 14), whereas the shape of deirids is the same (Fig. 5 B) as in adults (Fig. 4 D). The presence of only six prostomal teeth in fourth-stage larvae is also characteristic of some other species of Rhabdocho$n a$ with 10 or 14 teeth in adults [e.g., R. ergensi Moravec, 1968, R. hellichi (Šrámek, 1901), R. oncorhynchi (Fujita, 1921), R. phoxini Moravec, 1968 - Moravec 1972a, 1976, 1995, Shimazu 1996].

The data presented above indicate that $R$. hospeti mainly parasitizes fishes of the genus Tor and is widely distributed in India, Pakistan and in the Indus River basin in Afghanistan; it also occurs in Malaysia.

\section{Rhabdochona (Globochona) mazeedi Prasad et} Sahay, 1965

Figs. 6, 7

Syns: Rhabdochona dasi Sahay et Prasad, 1965; R. yarrelli Verma, 1972; R. cavasius Rehana et Bilqees, 1973.

Description: Medium-sized nematodes with transversely striated cuticle (Fig. 7 B-E). Oral aperture hexagonal, surrounded by four small submedian cephalic papillae; sublabia indistinct; pair of lateral amphids present (Figs. 6 C, 7 A, B). Prostom funnel-shaped; small basal prostomal teeth slightly outlined (Fig. 6 A, B). Anterior margin of prostom armed internally with 8 fairly large, forwardly directed teeth ( 2 dorsal, 2 ventral and 2 on each side) 

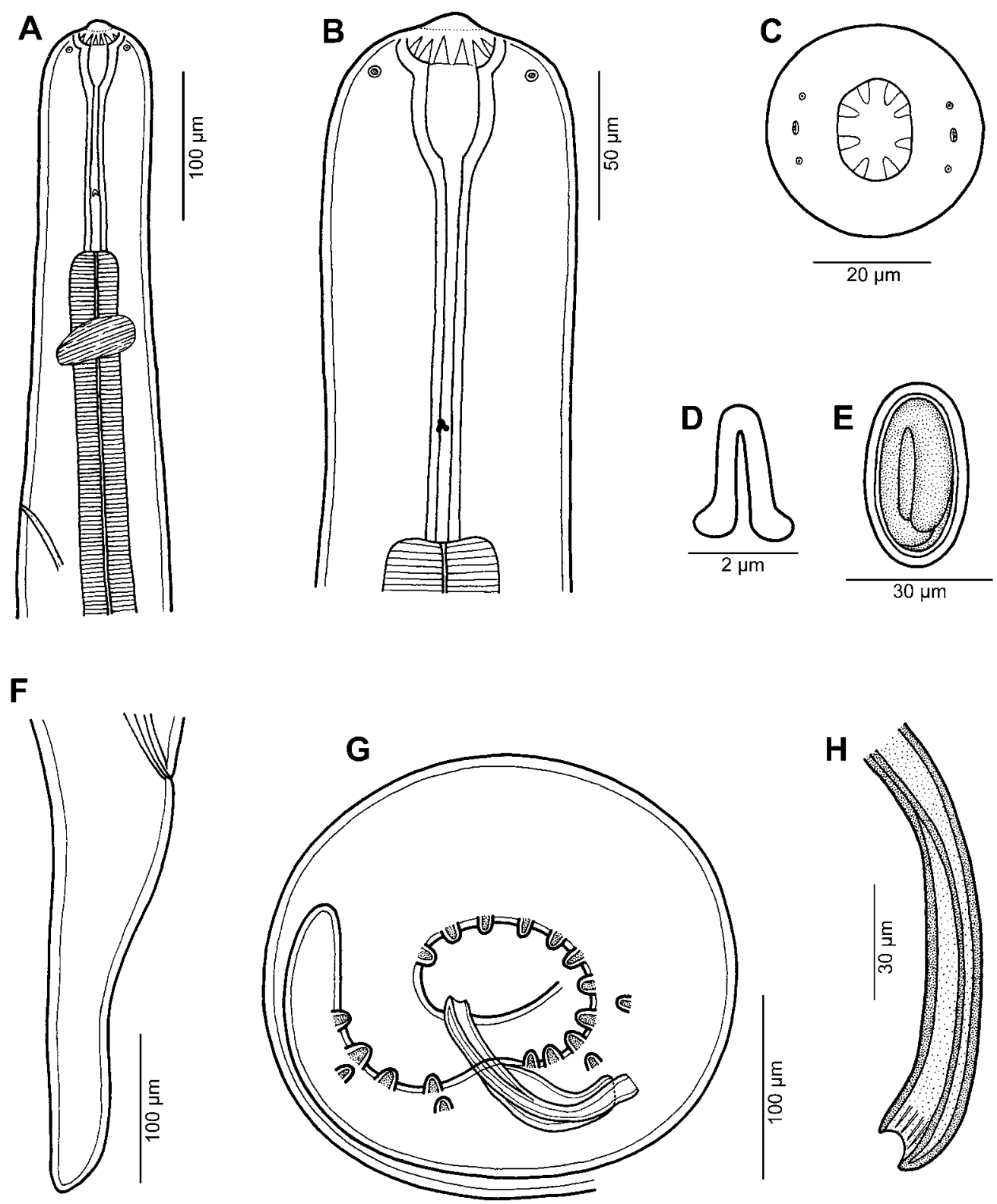

Fig. 6. Rhabdochona (Globochona) mazeedi Prasad et Sahay, 1965 from Clupisoma garua. A - anterior end, lateral view; B, C - cephalic end, lateral and apical views; D - deirid; $\mathbf{E}$ - fully developed egg; $\mathbf{F}$ - female tail, lateral view; $\mathbf{G}$ - posterior end of male, lateral view; $\mathbf{H}$ - distal end of left spicule, lateral view.

(Figs. 6 C, 7 A, B). Vestibule of medium length (Fig. 6); surface of vestibule finely transversely striated. Deirids small, bifurcate, with narrow, fairly long arms conspicuously expanded at distal ends, resembling thus human legs (Figs. 6 D, 7 C); deirids situated at level of posterior half of vestibule (Fig. 6 A, B). Tail of both sexes conical, with rounded tip (Figs. 6 F, G, 7 F).

Male (1 specimen): Length of body $9.75 \mathrm{~mm}$, maximum width 150. Prostom 45 long and 27 wide in lateral view. Length of vestibule including prostom 186. Muscular oesophagus 462 long, maximum width 42; glandular oesophagus $2.58 \mathrm{~mm}$ long, maximum width 109 ; length ratio of both parts 1:5.6. Length of vestibule with prostom and entire oesophagus forms $33 \%$ of body length. Nerve ring encircling muscular oesophagus 264 from anterior extremity; excretory pore at 390 . Preanal papillae: 10 subventral papillae on one side and 11 papillae on opposite side; additional 2 pairs of lateral papillae situated at level of third, and between fourth and fifth subventral pairs (counting from cloacal opening) (Figs. 6 G, 7 E, F). Postanal papillae: 6 pairs, of which 4 pairs subventral and 2 lateral; lateral pairs approximately at level of first and third pairs of subventrals (Fig. $6 \mathrm{G}$ ). Longitudinal ventral cuticular ridges (area rugosa) not observed. Left spicule 


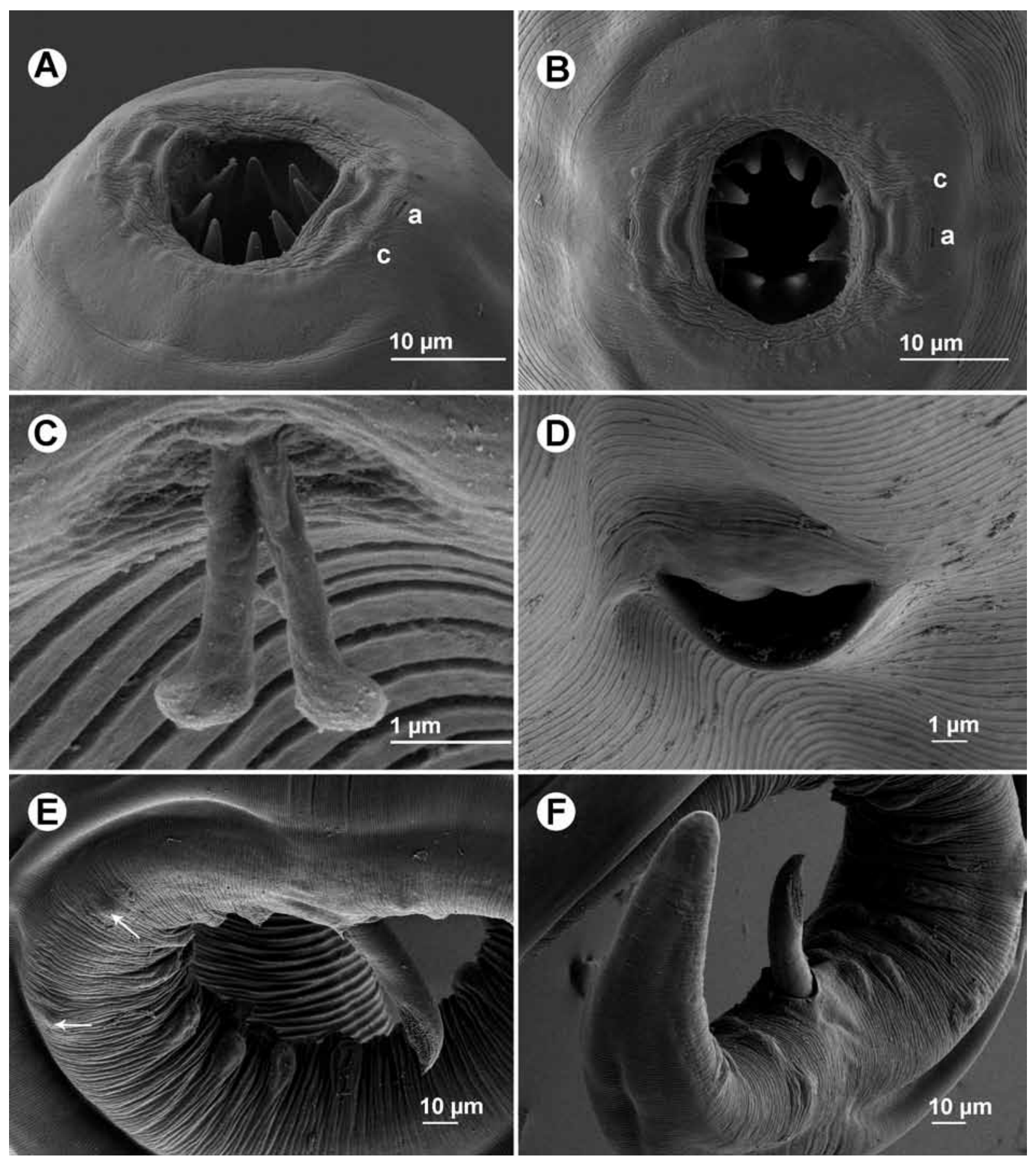

Fig. 7. Rhabdochona (Globochona) mazeedi Prasad et Sahay, 1965 from Clupisoma garua, scanning electron micrographs. A, B - cephalic end, dorsoventral and apical views; $\mathbf{C}$ - deirid; D - excretory pore; $\mathbf{E}$ - preanal region of male posterior end, lateral view (arrows indicate lateral papillae); $\mathbf{F}$ - posterior end of male, ventrolateral view. Abbreviations: a - amphid; c - external cephalic papilla.

markedly short, 192 long; its shaft 81 long, representing $42 \%$ of entire spicule length; distal tip of extruded spicule slightly widened, blunt (Fig. $6 \mathrm{H}$ ). Right spicule boat-shaped, 120 long, without dorsal barb at distal tip (Fig. $6 \mathrm{G}$ ). Length ratio of spicules 1:1.6. Tail 252 long, with rounded tip (Figs. 6 G, 7 F).
Female (2 gravid specimens): Length of body 17.76 $19.68 \mathrm{~mm}$, maximum width 258-272. Prostom 48-57 long and 33-36 wide in lateral view. Length of vestibule including prostom 171-180. Muscular oesophagus 556-598 long, maximum width 51-54; glandular oesophagus 2.87-3.24 mm, maximum width 129-159; length ratio of both parts 1:5.2-5.4. Nerve ring, excretory pore 
and deirids at 243-255, 367-408 and 135, respectively, from anterior extremity (Fig. 6 A). Vulva postequatorial, $9.56-10.65 \mathrm{~mm}$ from anterior extremity (at $54 \%$ of body length) (Fig. 7 D). Vagina directed posteriorly from vulva. Fully developed eggs elongate-oval, thick-walled, smooth, containing larvae (Fig. 6 E); eggs 42-45 long and 24 wide, thickness of their wall 3. Tail 285-340 long, with rounded tip (Fig. 6 F).

Hos t: Garua bachcha, Clupisoma garua (Schilbeidae, Siluriformes).

Site of infection: Intestine.

L ocality: Farakka Dam Lake on the Ganges River, West Bengal, India (collected 3 March 2009).

Prevalence and intensity: In 2 fish examined; 1 and 4 specimens.

Deposition of voucher specimens: IPBCAS (Cat. No. N-936).

Comments. The general morphology of the present specimens, especially the markedly short left spicule, is most similar to the inadequately described Rhabdochona mazeedi Prasad et Sahay, 1965, a species originally described from the catfish Eutropiichthys vacha (Hamilton) (Schilbeidae) in the Ganges River drainage system (Patna, Bihar), India (Prasad and Sahay 1965). Since the host fishes of both forms are also related and belong to the same family, and both these nematode forms occur in the same river basin, the present nematodes are considered to belong to this species.

One of the most important taxonomic features in Rhabdochona is the number of anterior prostomal teeth (Moravec 1975, 2010). Prasad and Sahay (1965) reported 10 ("5 pairs") prostomal teeth in $R$. mazeedi; however, they studied them in a lateral view, so that their information is not reliable, because the exact number of these teeth can only be established in an apical view, preferably using SEM (Moravec 1972b, 2007). Based on the general morphology, Moravec (1975) assigned R. mazeedi to the morphological group A of his re-diagnosed subgenus Globochona Moravec, 1972, characterized by the presence of 8 prostomal teeth. This number in $R$. mazeedi is confirmed by the present SEM study.

Prasad and Sahay (1965) could not find any deirids and the location of the excretory pore in $R$. mazeedi, although these represent important taxonomic features. As we have found using SEM, the deirids of this species have a unique shape within Rhabdochona (see Moravec 2010); the cephalic papillae and amphids of $R$. mazeedi are also described for the first time in this paper. In the original description, Prasad and Sahay (1965) reported and illustrated 12 pairs of preanal and 5 pairs of postanal subventral caudal papillae in the male of $R$. mazeedi, but no lateral papillae. In contrast, we found 10 and 11 subventral preanal papillae and 2 lateral preanal papillae, and 4 pairs of subventral and 2 of lateral postanal papillae, which were confirmed by SEM. It may well be that the numbers of papillae reported in the original description were based on inaccurate observations, although a certain degree of intraspecific variability in the number of preanal papillae in Rhabdochona spp. does frequently occur (Moravec 1972a). A characteristic feature of $R$. mazeedi is its unusually short left spicule; the shaft of this spicule, which may also be a taxonomic feature, is described for the first time.

Two inadequately described Indian species, Rhabdochona dasi Sahay et Prasad, 1965 and $R$. yarrelli Verma, 1972, parasites of catfishes Ompok pabda (Hamilton) (Siluridae) and Bagarius yarrelli (Sykes) (Sisoridae), respectively (see Sahay and Prasad 1965, Verma 1972), were synonymized by Moravec (1975), and Moravec and Daniel (1976) added another synonym, $R$. cavasius Rehana et Bilqees, 1973, a poorly described species from the catfish Mystus cavasius (Hamilton) (Bagridae) in Pakistan (Rehana and Bilqees 1973). This was followed by Soota (1983), but Sood (1988) considered $R$. yarrelli a distinct species, with $R$. cavasius as its junior synonym. In our opinion, there is no reason for considering $R$. yarrelli to be a species distinct from $R$. mazeedi.

Acknowledgements. Stay of one of the authors (T. S.) in India in 2009 was realized under the Indian National Sciences Academy (INSA) - Academy of Sciences of the Czech Republic (ASCR) Bilateral Exchange Programme. A collection trip in West Bengal in March 2009 was financially and logistically supported by the Jhargram Raj College in Jhargram, Paschim Medinipur, West Bengal. Special thanks are due to Amritendu Mondal, Debsekhar Nath, Tinkori Bhui and Saurav Sarkar for invaluable help during the collecting and parasitological examination of fish. Collecting in Northern Bengal (Darjeeling district) and Sikkim would not have been possible without the generous help of Rujas Yonle (Darjeeling Governmental College). We also wish to thank the staff of the Laboratory of Electron Microscopy, Institute of Parasitology, Biology Centre of the Academy of Sciences of the Czech Republic, ASCR, České Budějovice for technical assistance and Blanka Škoríková, Department of Helminthology at the same institute, for help with the illustrations. This study was partly supported by the research projects of the Institute of Parasitology, ASCR (Z60220518 and LC522) and the Grant Agency of the Czech Republic (524/08/0885 and 206/09/H026).

\section{REFERENCES}

Ashurova M. 1973: [The fish parasites of Lake Sarez (Pamir)]. Parazitologiya 7: 164-168. (In Russian.)

Bykhovskaya-Pavlovskaya I.E. 1936: [The fauna of endoparasites of fishes from the River Chu.] In: Vol. "Rybnoe Khozyaystvo Kirgiz. SSR”, Izd. AN SSSR, Moscow-Leningrad, pp. 277-294. (In Russian.)
ČERnotíkovÁ E. 2010: [Molecular phylogeny of selected species of fish nematodes of the suborder Spirurina inferred from SSU rRNA gene sequences.] Unpublished MSc. thesis, Faculty of Science, University of South Bohemia, České Budějovice, 48 pp. (In Czech.) 
Duggal C.L., Kaur H. 1987: Rhabdochona moraveci sp. nov. (Nematoda: Rhabdochonidae) from a freshwater fish, Barbus tor in Punjab, India. Res. Bull. (Sci.) Panjab Univ. 38: 137-139.

DzhaliLov U.D. 1964: [Rhabdochonid materials (Rhabdochona Railliet, 1916) from fishes of the River Vakhsh and nearby lakes]. Izv. AN Tadj. SSR, Otd. Biol. Nauk, 1 (15): 109-117. (In Russian.)

Fotedar D.N., Dhar R.L. 1970: On the morphology of Filochona kashmirensis (Thapar, 1950) from freshwater fishes of Kashmir. Kashmir Sci. 7: 107-110.

Froese R., Pauly D. (Eds.) 2010: FishBase. World Wide Web electronic publication, www.fishbase.org, version 05/2010.

Furtado J.I. 1965: Rhabdochona penangensis sp. nov. (Nematoda, Rhabdochonidae) from a Malayan cyprinid fish. Zool. Anz. 174: 231-236.

KaKar A., BILqees F.M. 2007a: Two new species of Rhabdochona Railliet, 1916 (Nematoda: Rhabdochonidae) from the fishes of Hingol River and Bolan River of Balochistan. Proc. Parasitol. 44: 29-39.

KaKar A., Bilqees F.M. 2007b: Rhabdochona uvaginus, new species (Nematoda: Rhabdochonidae) from the fish Tor putitora of River Bolan, Balochistan. Pak. J. Zool. 39: 51-55.

Kakar A.U., Bilqees F.M., Ahmad S. 2008: Two new species of the genus Rhabdochona Railliet, 1916 (Nematoda: Rhabdochonidae) from the fish Tor putitora (Cyprinidae) from Bolan, Balochistan, Pakistan. Pak. J. Nematol. 26: 21-28.

KaLYANKAR S.D. 1972: On some interesting nematodes of fishes from India. Riv. Parassitol. 33: 281-288.

Karve J.N., Naik G.G. 1951: Some parasitic nematodes of fishes - II. J. Univ. Bombay, New Ser., 19: 1-37.

Katoch K., Kalia D.C. 1991: Nematode parasites of vertebrates from Himachal Pradesh I: On a new species Rhabdochona $(R$. moraveci (family: Rhabdochonidae Skrjabin, 1946) from fresh water fishes from Beas River. Ind. J. Helminthol. 43: 88-91.

Malhotra S.K., Rautela A.S. 1984: A new rhabdochonid nematode, Comephronema [sic] mackiewiczi n. sp. from a hillstream teleost of a new zoogeographical region. Riv. Parassitol. 45: 285-291.

Mejía-Madrid H.H., Choudhury A., Pérez-Ponce de León G. 2007: Phylogeny and biogeography of Rhabdochona Railliet, 1916 (Nematoda: Rhabdochonidae) species from the Americas. Syst. Parasitol. 67: 1-18.

Moravec F. 1972a: Studies on the development of the nematode Rhabdochona (Filochona) ergensi Moravec, 1968. Folia Parasitol. 19: 321-333.

Moravec F. 1972b: General characterization of the nematode genus Rhabdochona with a revision of the South American species. Acta Soc. Zool. Bohemoslov. 36: 29-46.

Moravec F. 1975: Reconstruction of the nematode genus Rhabdochona Railliet, 1916 with a review of the species parasitic in fishes of Europe and Asia. Studie ČSAV, Academia, Praha, $104 \mathrm{pp}$.

Moravec F. 1976: Observations on the development of Rhabdochona phoxini Moravec, 1968 (Nematoda: Rhabdochonidae). Folia Parasitol. 23: 309-320.

Moravec F. 2007: Some aspects of the taxonomy and biology of adult spirurine nematodes parasitic in fishes: a review. Folia Parasitol. 54: 239-257.

Moravec F. 2010: Some aspects of the taxonomy, biology, possible evolution and biogeography of nematodes of the spirurine genus Rhabdochona Railliet, 1916 (Rhabdochonidae, Thelazioidea). Acta Parasitol. 55: 144-160.

Moravec F., Amin A. 1978: Some helminth parasites, excluding Monogenea, from fishes of Afghanistan. Acta Sci. Nat. Brno 12: $1-45$.

Moravec F., Daniel M. 1976: Rhabdochona minima sp. n. (Nematoda: Spiruroidea) from the loach, Noemacheilus inglisi (Hora), of Nepal. Folia Parasitol. 23: 175-178.

Moravec F., Řína M., Kuchta R. 2008: Two new nematode species, Paragendria papuanensis sp. n. (Seuratoidea) and Rhabdochona papuanensis sp. n. (Thelazioidea), from freshwater fishes in Papua New Guinea. Folia Parasitol. 55: 127-135.

Osmanov S.O. 1971: [Parasites of Fishes of Uzbekistan]. Publ. House "EAN" Uzbekskoy SSR, Tashkent, 532 pp. (In Russian.)

Paul B., Majumdar G. 1994: Description of a new species of the genus Rhabdochona (Nematoda: Spiruridae). Environ. Ecol., W. Bengal, 12: 854-856.

Prasad D., Sahay U. 1965: On Rhabdochona mazeedi sp. nov. (Thelaziidae, Rhabdochoninae, Rhabdochona, Railliet, 1916) from the intestine of Eutropiichthys vacha. Ind. J. Helminthol. 17: $43-48$.

Rehana R., Bilqees F.M. 1973: Rhabdochona cavasius sp. n. (Nematoda: Rhabdochonidae) from a fish Mystus cavasius (Ham.) from Kalri Lake, Sind. Pak. J. Sci. Ind. Res. 16: 110-111.

Sahay U., Prasad D. 1965: On Rhabdochona dasi sp. nov. (Thelaziidae, Rhabdochoninae, Rhabdochona Railliet, 1916) from a fresh water fish Callichrous pabda (Hamilton). Jpn. J. Med. Sci. Biol. 18: 311-316.

Shimazu T. 1996: Mayfly larvae, Ephemera japonica, as natural intermediate hosts of salmonid nematodes, Sterliadochona ephemeridarum and Rhabdochona oncorhynchi, in Japan. Jpn. J. Parasitol. 45: 167-172.

SiddiQi M.N., Khattak A.R. 1983: Helminth parasites of fishes of N. W. F. P. (Pakistan). Pak. Vet. J. 3: 84-86.

SKRYABIN K.I. 1917: [On the recognition of the helminth diseases of some fishes in Russia.] Arkh. Vet. Nauk 3-5: 522-543. (In Russian.) (Ex Skryabin 1923).

SKRYABIN K.I. 1923: [Parasitic nematodes of the freshwater fauna of the European and partly Asiatic Russia.] In: Freshwater fauna of European Russia, Vol. 2. Publ. Houses "Priroda" and "Nauchrybbyuro", Moscow, 98 pp. + i-xxxiii + 20 Plts. (In Russian.)

Sood M.L. 1972: Two nematode parasites (Rhabdochonidae Skrjabin, 1946) from fresh water fishes of India. Zool. Anz. 188: 100-106.

Sood M.L. 1988: Fish Nematodes From South Asia. Kalyani Publishers, New Delhi, 703 pp.

SoотA T.D. 1983: Studies on nematode parasites of Indian vertebrates I. Fishes. Records of the Zoological Survey of India, occasional paper no. 54. Zoological Survey of India, Calcutta, $352 \mathrm{pp}$.

Soota T.D., SARKar D.S.R. 1981: On some nematodes from Solan District, Himachal Pradesh, India. Rec. Zool. Surv. India 79: $169-177$

Thapar G.S. 1950: Two new species of the genus Rhabdochona Railliet, 1916 from Indian fishes. Ind. J. Helminthol. 2: 35-40.

VERMA S.L. 1972: Helminth parasites of fresh water fishes VIII. On two species of the genus Rhabdochona Railliet, 1916 from Lucknow. Jpn. J. Parasitol. 21: 296-301. 